\title{
STUDIES ON THE INOCULATION TO DIFFERENT ANIMALS OF LEPROSY BACILLI (The 3rd Report)
}

On the Susceptibility of Cats and Nutrias with M. Leprae Murium

Yasuro TAKAYAMA

Dept. of Bacteriology, Hiroshima University Medical School (Prof. Urabe)

After the intraperitoneal inoculation of murine leprosy bacillus suspension to cats and nutrias, the intraperitoneal fluid was collected, of which migrating cells, phagocytotic cells and extracellular acid-fast bacilli were investigated. Moreover, distribution of bacilli were examined by autopsy.

The results of examination of susceptibility of these animals to the murine bacillus were as following.

1) The bacilli inoculated into the intraperitoneal cavity produced no infectious finding after 2 months, though in some cases they presented a picture of multiplication in the testis. After staying 2 months in cats, the bacilli still kept infectiousness to white rats.

2) Inoculation of the murine bacilli into the intraperitoneal cavity of nutrias produced no murine leprosy.

3) Multiplication of bacilli in the migrating cells of intraperitoneal cavity could not be observed not only in cats and nutrias, but also in white rats.

4) The intraperitoneal migrating cells were not different in the properties between cats or nutrias and white rats. But the migrating stadium of monocytes and neutrophile leucocytes were different in cats and nutrias and in white rats.

\section{攋菌の異種動物接種に関する研究 \\ 第 3 報 猫及びヌートリアの鼠癩菌に対する \\ 感受性について \\ 広島大学医学部細菌学教室（指導 占部教授）}

高山保郎

（昭和31年 7 月 7 日 受稿）

(本論文の内容要旨は第 27 回, 第 28 回日本獺学会総会に於て報告した)一交部省科学研究費による研究（占部）一

緒言

䎁癩菌の動物接種実験は，すてに諸種の動物を用いて 内外多の学者 ${ }^{1212)}$ によりこころみられているにも拘 わらず，いま坑確実な鼠瀨菌感受性動物としては,鼠科, 栗鼠科 ${ }^{13) 14}$ 以外の。の住付けられていないよ5で女 る。

本来鼠䍩菌に対して感受禇のない動物に対してその感 染を成立させるよらな何らかの方法を見付けるか，或は
鼠䅋菌感受性動物之同韭感受性動物之の閻の何らかの感 受性交配因子のようなるを見出すかするととは，今日 な打，不可能視されているとてろの人霜菌の実験動物人 の感染成立の目的奎成の上に抢そらくは少からず貢献す るでらうととが考えられる。

このよ5な見地からして著者仕鼠瀨菌の異種動物接種 実験を企て，種々研究をかさねつつあるあのであるが， その結果の一部として，すてに鼠㰓菌に対してハムスタ 一が感受性を有することを認めえたととについて報告 ${ }^{5}$ 
したが，今回は同しく異種動物であるととろの猫並びに ヌートリアを供試した結果得られた成績について報告す る。

\section{第 1 章＼cjkstart猫に対する接種実験} 実験 I

\section{1. 実験方法}

a) 供試獣：体重 $800 \sim 1,800 \mathrm{~g}$ の猫4 匹を用い対照 としては 200 300g の白鼠 4 匹尼供試した。

b）供試鼠濑菌：鼠瘦熊本株感染白鼠の灀性肉芽 （接種後 177 日）上り生塩水による20倍乳郕の $1,000 \mathrm{r}$. p. m， 5 分後の上清を猫及びラッテ各 2 匹ずつの体重 $150 \mathrm{~g}$ Kつき $0.5 \mathrm{cc}$ 宛腹腔内に接種したはかに，同種菌 液の $100^{\circ} \mathrm{C} ， 20$ 分間加熱したものを上と同数の雨種試獣 の腹腔内に体重 $150 \mathrm{~g}$ につき $0.5 \mathrm{cc}$ 宛注入した。

c）観察：週 1 回の体重測定及び体表变化の観察の 他比，菌接種後 1 日， 4 日， 7 日，10日， 2 週，3週， 4. 週，5週，6週， 7 週，9週目に猫では注射器で，白 鼠では毛細管ピペットでそれぞれ腹腔液を採取し，法に 従つて整抹標本をつくり，炎机に Giemsa 染色及びZiehlNeelsen 染色を施したものについて，各標本 100 視野每 に打ける腹腔内出現細胞，哙菌細胞及び細胞外遊離抗酸 菌の時間的推移を追究した。

剖検は菌接種後 9 週目に行らととを原則としたが，猫

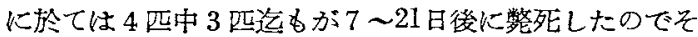
の都度剖㛟しそれらの所見も成績に加えるととにした。 部検時には淋巴腺（左右膝へき，同腋窩及び頸部，腸骨， 腸間膜，肝門）亚びに内淢（肺，肝，睥，腎，副腎，睪 丸(卵笨)，副睪丸）の肉既的所見亚びにそれらよりの

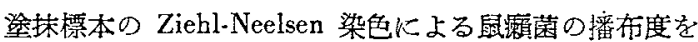
追究し且つそれらの病理組織学的観察をも行つた。

\section{2. 実験成績}

a)一般状態新び体表所見：生菌接種猫 1 匹 (No. 2) 及び死菌接種猫 2 匹 (No. 3，No. 4) は菌接種後上 り著しく元気を失い，No. 4 は 7 日目に No. 2, No. 3 は 21日目に整死した。な打体重は白鼠では渐增したのに対 して，猫では何れる減少したが，ただ No. 1 のみは专 験後期になつてやや增加した。体表所見には猫，白鼠両 群ともに終始特にいらほとの变化は認められなかつた。

b）腹腔液の所見：

i) 性状一猫で结生・死菌接種雨群之も初期代於てや や褐色を呈したが，漸次透明になり菌接種後10日目では 全く透明になつた。白鼠に於ては生・死菌接種亚群とも 猫火比し腹腔液の䖪濁度は上り軽く I 週目には全く透明 になつた。 ii）遊走細胞の所見一猫及び白鼠腹胉内人の出現細胞 としては中性好性白血球，単核球のはかにッンパ球，エ オヂン好性白血球，笰膜細胞及び肥渵細胞が検出され た。それらのちち比較的高率に検出された中性好性白血 球及び単核球の推移はFig. 1 及び Fig. 2 に示したよう であつて，猫に於ては生・死菌接種の別なく接理翌日に 社単核球比してはるか比多くの中性好性白血球が出現 したが，その後佉 4 日目須には前者漸堌，後者漸城のた めこれら両種細胞曲線に明らかな交叉がみられ，それ以

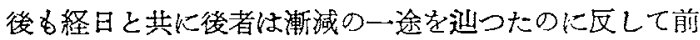
者は递に潮增した。之炕対して白鼠に於ては生・死菌接 種をとわず接種 1 日後の上記两種細胞の出現頻度には著

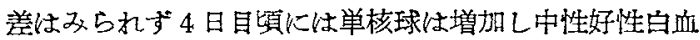
球は淢少したが, そのためにとれら両種細胞の推移曲線 には猫の場合のよ5な4 日目前後に怙ける交叉は諗めら れなかつたと云う点で上の猫に於ける所見とかなり趣を 異にしていた。しかしその後の経日につれての単核球の 漸增と中性好性白血球の漸隇との傾向に於ては忹ぼ揆を 一にしていた。

な拓，単核球て性初期儿特に大単核球伦於て多数の空 泡が原形質内代認めら九，又核の不鮮明なもの或は異常 に核のとわれたすのが可成り多数に認められ，末期にな ると小空泡が原形質内に認められるものがわずか火出現 し正常形態が多く検出されるようになつたが，かかる所 見に於ては生・死接種群間にも文猫，白鼠間にるいら以 どの差はなかつた。

Fig. 1. Transition of neutrophil leukocytes and monocytes appeared in the peritoneal cavities of cats

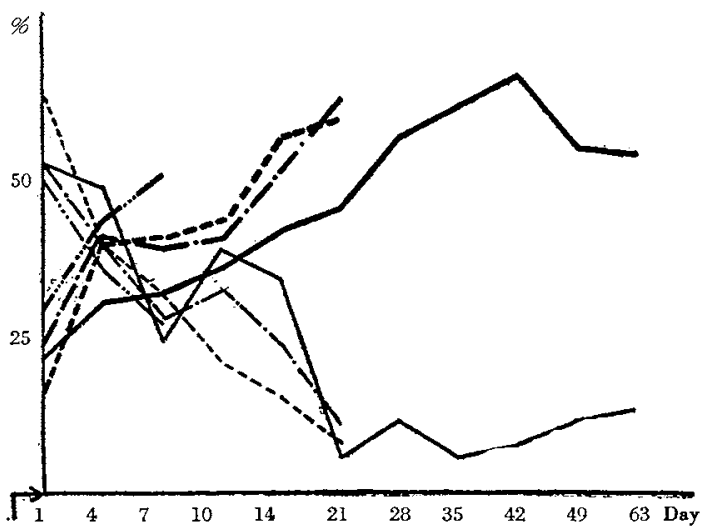
Days after inoculation

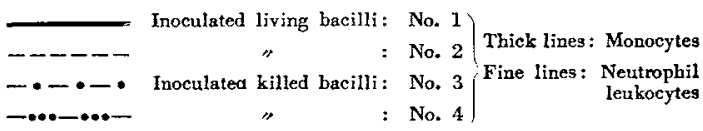


Fig. 2. Transition of neutrophil leukocytes and monocytes appeared in the peritoneal cavities of rats

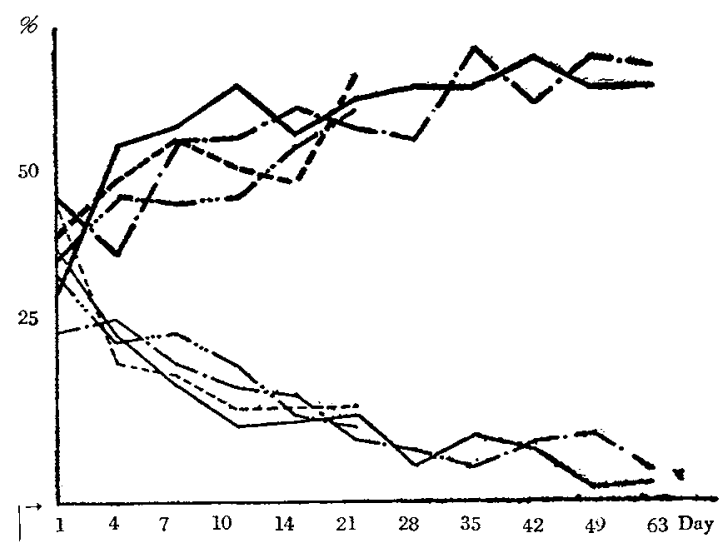

Days after inoculation

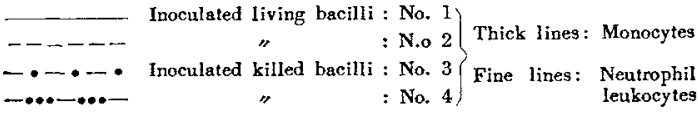

iii）喰菌細胞亚びに橹出菌の肵見一喰菌細胞として はその種類に於ては殆ど単核球で占められ，稀に中性好 性白应球，漿膜細胞ふ語められた。これらの脍菌細胞の 時間的推移は Fig. 3，Fig. 4 火見られるよらであつて菌 接種後早期には接種菌の生，死及び猫，白鼠の別を間わ すいずれす比較的多数認められたが，その後漸惐の一途 を这つた。但し生菌接種白鼠 2 匹の5ち 1 匹に於てはそ の減少曲線が比較的緩漫であつたが，猫に於ては同しく 生菌接種の 2 匹共急降下曲線を示したといら多少の差が 禹艃動物間に見られた。

次に被冒哙菌の形態についてみるに，接種媵初期には 多数の菌塊が細盷内に検出されたが，その後漸次菌長は

Fig. 3. Transition of phagocytes in the peritoneal cavities of cats

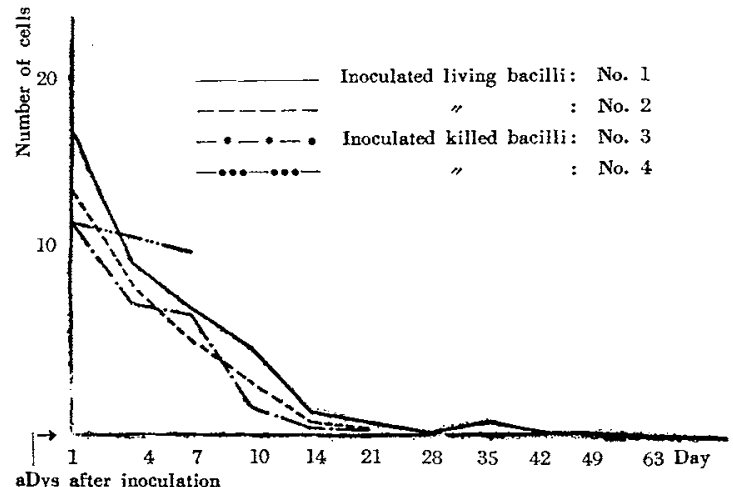

aDys after inoculation
一般に短縮，膨大の傾问を示すよらになり，顆粒もより 明蹽になつてくるようでめり，さらに接種 3 ４週後頃 になると恰る顆粒のみのようになつてくるととが狅ば同 样に接種菌の生，死及び動物の種類に関係なく認められ 又何れの時期を通してす生菌接種の猫及心゙同白鼠の腹空 内の遊離細胞内では抗酸菌の堌殖したと，思われる所胃は 認め難かつた。

Fig. 4. Transition of phagocytes in the peritoneal cavities of rats

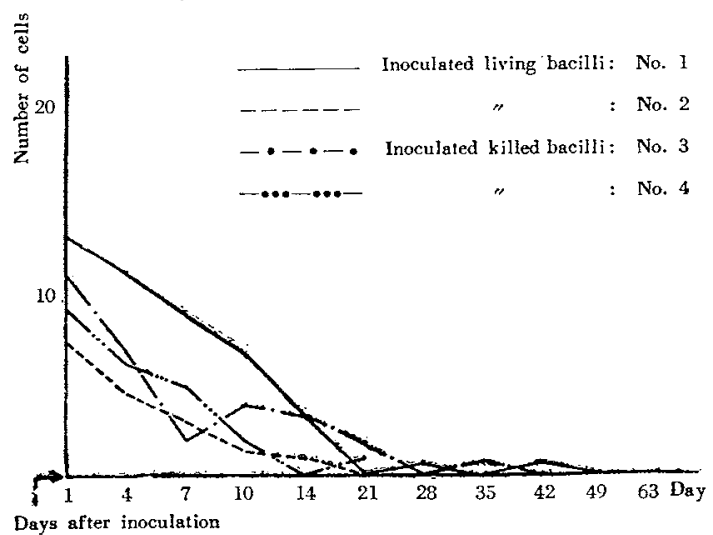

iv）細胞外遊離坑酸菌の所見一Table 1 に示したが 猫, 白鼠共に生・死菌接種の別なく，菌接種 1 日聁には かずかながら挖酸菌が賭腔内の細胞外に癹められたが， 猫では 4.日後にはすでに菌証明㓌性に終つたのに反し て，白鼠では4日後にすな拓少数乍ら抗酸菌が認められ その後になつてからは一応消失した。

Table 1. Transition of the extracellular acid-fast bacilli in the peritoneal cavities of cats and rats

\begin{tabular}{|c|c|c|c|c|c|c|c|c|c|c|c|c|c|}
\hline \multicolumn{3}{|c|}{\begin{tabular}{|l} 
\\
Animals \\
\end{tabular}} & I & 4 & 7 & 10 & 14 & 21 & 28 & 35 & 42 & 49 & 63 \\
\hline \multirow{4}{*}{ తే } & \multirow{2}{*}{ 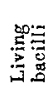 } & 1 & 1 & 0 & 0 & 0 & 0 & 0 & 0 & 0 & 0 & 0 & 0 \\
\hline & & 2 & 0 & 0 & 0 & 0 & 0 & 0 & & & & & \\
\hline & \multirow{2}{*}{ 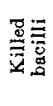 } & 3 & I & 0 & 0 & 0 & 0 & 0 & & & & & \\
\hline & & 4 & 3 & 0 & 2 & & & & & & & & \\
\hline \multirow{4}{*}{ ت्ञ } & \multirow{2}{*}{ 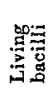 } & 1 & 3 & 1 & 0 & 0 & 0 & 0 & 0 & 2 & 0 & 0 & 0 \\
\hline & & 2 & 0 & 1 & 0 & 0 & 0 & 0 & & & & & \\
\hline & \multirow{2}{*}{ 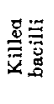 } & 3 & $I$ & 1 & 0 & 0 & 0 & 0 & 0 & 0 & 0 & 0 & 0 \\
\hline & & 4 & 0 & 0 & 0 & 0 & 0 & 0 & & & & & \\
\hline
\end{tabular}

Notice: The number shows the bacilli detected from 100 mieroscopic fields. 
c) 肉腿的剖検所胃：生菌接種猫 No. 2(21日後死) をはその右側滕べき部皮下に带緑黄色粘稆な膿を容れた 赤褐色米粒大結節を，又その大網には赤褐色丞粒大結節 が一面に散在した。死菌接種 No. 3(21日後死)ではそ

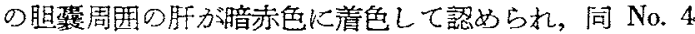

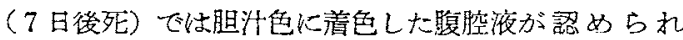
to

次に生藏接種白鼠 No. 1 (63日後殺) では腸間膜の肥 厚之瘾着が見られ，骨盤脂肪組織の著明な堌殖があり， 㕛同 No. 2（21日後殺）では左等に半米粒大の円现白色

Table 2. Degree of the distribution of acid-fast bacilli in the bodies of cats and rats

\begin{tabular}{|c|c|c|c|c|c|c|c|c|c|c|}
\hline \multicolumn{3}{|c|}{ Animals } & \multicolumn{4}{|c|}{ Cat } & \multicolumn{4}{|c|}{ Rat } \\
\hline \multicolumn{3}{|c|}{$\begin{array}{l}\text { Kind of murine lep. } \\
\text { bacilli used for } \\
\text { inoculation }\end{array}$} & \multicolumn{2}{|c|}{$\begin{array}{l}\text { Living } \\
\text { bacilli }\end{array}$} & \multicolumn{2}{|c|}{$\begin{array}{l}\text { Killed } \\
\text { bacilli }\end{array}$} & \multicolumn{2}{|c|}{$\begin{array}{l}\text { Living } \\
\text { bacilli }\end{array}$} & \multicolumn{2}{|c|}{$\begin{array}{l}\text { Killed } \\
\text { bacilli }\end{array}$} \\
\hline \multicolumn{3}{|c|}{ No. } & 1 & 2 & 3 & 4 & $I$ & 2 & 3 & 4 \\
\hline \multicolumn{3}{|c|}{ Survival days } & $\begin{array}{c}63 \\
\text { (s) }\end{array}$ & (D) & (D) & (D) & $\begin{array}{c}63 \\
(5)\end{array}$ & $\begin{array}{l}21 \\
(\mathrm{~S})\end{array}$ & $\begin{array}{c}63 \\
\mathrm{~s}) \\
\end{array}$ & $\begin{array}{c}21 \\
(\mathrm{~S})\end{array}$ \\
\hline \multicolumn{3}{|c|}{ Sex } & 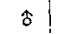 & 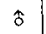 & 운 & 운 & $\widehat{o}$ & 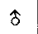 & 古 & 우 \\
\hline \multicolumn{3}{|c|}{ Initial bodyweight(g) } & $1800^{\prime}$ & $1080^{\circ}$ & $990^{\prime}$ & 810 & $180^{\circ}$ & 210 & 210 & 150 \\
\hline \multicolumn{3}{|c|}{ Inocul. dose(cc) } & 6.0 & 3.6 & 3.3 & 2.7 & 0.6 & 0.7 & 0.7 & 0.5 \\
\hline \multirow{9}{*}{ 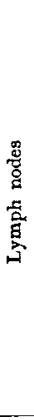 } & Knee fold & $\mathbf{r}$ & -1 & \pm & - & \pm & + & + & - & $\perp$ \\
\hline & 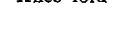 & I & + & - & - & - & -1 & - & - & - \\
\hline & \multirow{2}{*}{ Axillary } & $\mathbf{r}$ & - & - & - & - & -2 & \pm & - & - \\
\hline & & $\mathbf{I}$ & + & - & \pm & - & $\perp$ & - & - & - \\
\hline & \multirow{2}{*}{ Cervical } & $r$ & $-\vdots$ & - & - & - & + & - & $\perp$ & $\perp$ \\
\hline & & $\mathbf{I}$ & - & + & $\perp$ & - & \pm & + & 一 & $\perp$ \\
\hline & \multicolumn{2}{|l|}{ Iliac } & \pm 1 & $\perp$ & + & + & $\perp$ & + & $\perp$ & 2 \\
\hline & \multicolumn{2}{|c|}{ Mesenterial } & $+\mathrm{i}$ & $\perp$ & $\perp$ & + & + & +1 & $\perp$ & + \\
\hline & \multicolumn{2}{|c|}{ Porfalvein } & - & $\perp$ & - & + & $+i$ & + & & \\
\hline \multirow{7}{*}{ 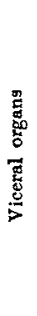 } & Lung & & $-\dot{i}$ & + & - & - & + & - & - & - \\
\hline & Liver & & +1 & + & $\perp$ & - & $=1$ & $\perp$ & - & - \\
\hline & Spleer & & $+\vdots$ & $\perp$ & + & - & $\perp$ & + & + & $\perp$ \\
\hline & Kidne & & - & $\perp$ & -1 & - & \pm & - & - & - \\
\hline & Suprarenal & land & . & +1 & +1 & - & +1 & $\perp$ & - & - \\
\hline & Testicle $(0$ & ary) & ${ }_{*} j$ & +1 & $\perp !$ & - & + & $\perp$ & - & - \\
\hline & Epididyn & & \pm 1 & - & & & \pm & - & - & \\
\hline
\end{tabular}

Notice:

※ : Loose glob

(S): Sacrifice

\begin{tabular}{|c|c|c|}
\hline Mark & Bacillary Counts & Microscopical Fields \\
\hline & 0 & $>100$ \\
\hline+ & ca. 10 & $100 \sim$ Several \\
\hline+ & 1 & 1 \\
\hline$t t$ & $1 \sim 10$ & 1 \\
\hline
\end{tabular}

結節が兌られたが，その他の死菌接種白鼠 No. 366 日 後殺) 及び No. 4 (21日後殺) kは特にい、万程の変化は 見受けられなかつた。

d）細菌学的所克：猫及び白鼠体内に於ける抗酸菌 の播布度は Table 2 に示したが，先ず生菌接種の場合 についてみるに猫に於ては白鼠に比して抗酸菌の体内播 布度は多少とも劣つて抢り，而子猫体内では菌形の短縮 形，膨隆形を示するの及び顆粒の判然とした菌の認めら れるととがより多かつだ。だ゙し生菌接檑猫 No.1の 睪丸に於て，細長，せん細な定型的鼠瀬菌を思方せる抗 酸菌が多数検出され，而もその他に鼠賈菌の Globi 前 期像を思わせる抗酸菌の集塊も少数ながら証明されたと とは注目に洒するすのと思市九た。文同 No. 2 の右側 膝へきき部の結節の膿には多数の顆粒形抗酸菌が認められ た。

死菌接種のさいに於ては猫，白鼠のいずれに於てもい 般的に双て上記の生菌接喠の場合に比して抗酸菌の体内 播布度は，わずか乍らより少く且つ靯と白鼠との間にも 総括的ていりてはとんど差が双られなかつた。

e ）病理組織学的所見：生菌接種白鼠では腸間膜淋 巴腺，肝及び脾に主として類円形細胞が集簿して大小種 々の鼠旗結節を形成し，Ziehl一マトキシリン染色に於 ても多数の菌が Globi 状顼至は散在状に認められたの に反し，生菌接種猫 No. 1 に於ては淋巴腺，肺，肝及

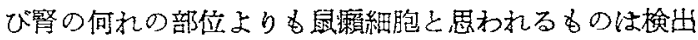

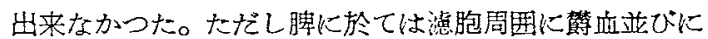
小出血点が認められ，鼠剩細胞と，思われる組織球性細胞 の小集団が僅かながら検出されたが，菌の被染性は不良

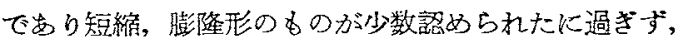
これは細胞内堌殖像とは摆加にかけ離れ大所見と思われ た。な技，前記の抗酸菌が多数認められ Globi 前期像も みられた睪丸の病理組織学的検索は，乙の睪丸を凡て細 菌学的検索に使用しつくしてできなかつたととはまてと に遗憾で为つた。

\section{実験 II}

\section{1. 実䀦方法}

a) 供試獣：初代接種猫では体重 $800 \sim 1,700 \mathrm{~g} の も の$ を2 匹宛生菌並びに死菌接程群として供試した。累代接 種猫としては体重 $1,100 \sim 1,400 \mathrm{~g}$ の猫を，生菌接種群 に2 匹及び死菌接種群に】匹それぞれ充てた。

b）供試鼠瀨菌：鼠瀨熊本㧣感染白鼠の制性肉芽（接 種後309日）より生塩水による20倍乳郕の1,00 r. p. m., 5 分徯の上清を，体重 $200 \mathrm{~g}$ につき $0.5 \mathrm{cc}$ 宛榎腔内接種 し，同時に右側膝べき部にもその $0.5 \mathrm{cc}$ 究を接種した。 
死菌接種群は $100^{\circ} \mathrm{C} ， 20$ 分間加熱された上記菌液を生菌 接種群同椂儿接種した。

暴代接種に於ては生菌挼種猫の睪丸の約30倍生塩水加 乳剂 $(2 \sim 3$ 視野に $1=$ の抗酸菌陽性) を健常猫の腹臆 内に $2 c c$ 宛注射し，同時心白鼠化も復元接種の目的でそ の右側膝べき部皮下へ $0.5 \mathrm{ce}$ 注射した。な拓，死菌累代 接種には上記の睪丸乳剂の $100^{\circ} \mathrm{C}, 20$ 分間加熱のものを 同量宛てた。

c）観察：遇 1 回の体重測定及び体表变化の観繁の他 に獘死後又は一定時日後に屠殺してさきの実験Ｉの場合 と同様にして剖検その他の諸检查を行つた。

\section{2. 実験成績}

a) 一般扷熊: Table 3 の上5に生菌接種猫 No. 5 は 菌接種後 1 日目に, 又死菌接種猫 No. 7 汢同 3 日目K,

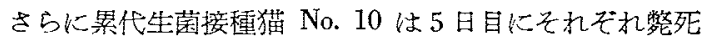
したが，その近の猫についていらと菌接種後早期仙は活

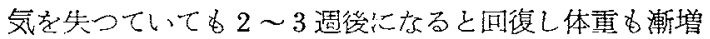
Lた。

b ）肉眼的测検所見：先ず初代接種猫について兒るに

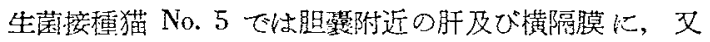
死菌接霾猫 No. 7 6該部の肝汇各々腤赤色の着色 部が

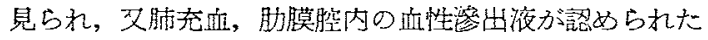
がその他の生菌接種猫 No. 6 及び死菌接㮐猫 No. 8 で はそれらの菌接種局所皮下（右側膝べき部) に橙黄色組 織で被包された $0.2 \times 0.4 \mathrm{~cm}$ の焱黒褐色組織が兌られた のみで腹腔内搭器とか淋巴腺とか火は特に顕著な所㫛は 見られなかつた。

累代接種猫に於ては生菌接種猫 No. 9 の大網の広笧 囲な癒着と，脾表面の辺縁に多数の粟粒大結節が認めら れたのみで，その他の No. 10，No. 11 の試濒では認む べき所見に接しなかつた。

c) 細菌学的所完：供試猫体内に拓ける抗酸菌の播布 度は Table 3 に示した。即ちこれでみられるよ5初 代の両接種群間に於ける抗酸菌の播布の程度には特心㙏

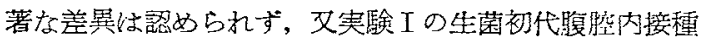
猫の睪丸内に見られた恰もGlobi 前期像の如き所見 (Table 2 参照) には今回は遂に接し得られなかつた。 2 代接理の猫伿於ては抗酸菌の体内播布度は初代接種 のさいのそれに比してさらに一段と稀少であつた。

な拓，猫体内に分布した抗酸菌怜令回子前回之略同様 にその形態に短縮，膨隆化がみられ，その他顆粒の明膫 化の及られるすの子多く，さらに菌体の被染性は初代接

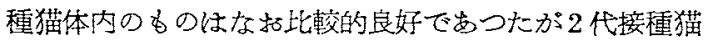
体内のすのに於てはすでにやや不良化していた。
Table 3. Degree of the distribution of acid-fast bacilli in the bodies of cats

\begin{tabular}{|c|c|c|c|c|c|c|c|c|c|}
\hline & Animals & & & st ger & eratios & & & gener: & ation \\
\hline $\begin{array}{l}\text { Kind } \\
\text { used }\end{array}$ & $\begin{array}{l}\text { f murine lef } \\
\text { or inoculation }\end{array}$ & $\operatorname{acilli} \bar{i}$ & & ing & $\begin{array}{l}\mathrm{Kil} \\
\mathrm{bac}\end{array}$ & & & ing & $\begin{array}{l}\text { Killed } \\
\text { bacillit } \\
\end{array}$ \\
\hline & No. & & 5 & 6 & 7 & 8 & 9 & 10 & 11 \\
\hline & Survival day & & (D) & $(5)$ & (D) & (D) & (S) & (D) & (S) \\
\hline & Sex & & $q$ & $\hat{o}$ & $\hat{o}$ & $q$ & $\hat{o}$ & q & $\hat{o}$ \\
\hline & al body weig & & 680 & 1,680 & 800 & 1,000 & 1,400 & 300 & 1,150 \\
\hline & ntraperitoneal & ocul. & 1.7 & 4.2 & 2.0 & 2.5 & 2.0 & 2.0 & 2.0 \\
\hline E: & $\begin{array}{l}\text { beutaneous } \\
\text { the right kne } \\
\end{array}$ & old at & 0.5 & 0.5 & 0.5 & 0.5 & & & \\
\hline Site & subcutaneou & nocul. & $\infty$ & $\infty$ & $\infty$ & $\infty$ & & & \\
\hline & & $\mathrm{r}$ & - & + & $\perp$ & $\perp$ & - & - & - \\
\hline & Anee lota & 1 & - & + & \pm & - & - & - & - \\
\hline & & $r$ & - & - & $\perp$ & - & - & - & - \\
\hline 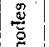 & - & I & \pm & - & - & $\perp$ & $\perp$ & - & - \\
\hline$E$ & Cervical & $\mathrm{r}$ & - & - & - & - & - & $\perp$ & - \\
\hline 독 & 年 & 1 & \pm & - & $\perp$ & - & - & - & - \\
\hline & Iliac & & $\perp$ & \pm & \pm & $\perp$ & - & $\perp$ & $\perp$ \\
\hline & Mesenter & & + & \pm & + & - & $\perp$ & - & - \\
\hline & Portalve & & + & \pm & + & $\perp$ & - & $\perp$ & $\perp$ \\
\hline & Lung & & \pm & $\perp$ & + & $\perp$ & - & - & - \\
\hline & Liver & & \pm & \pm & + & - & - & \pm & - \\
\hline E & Spleen & & $\perp$ & + & \pm & $\perp$ & - & $\perp$ & - \\
\hline $\bar{\Xi}$ & Kidney & & + & - & $\perp$ & $\perp$ & - & - & - \\
\hline$\stackrel{2}{5}$ & Suprarenal & & $\perp$ & \pm & + & - & - & $\perp$ & - \\
\hline & Testicle (OV & & $\perp$ & $\perp$ & +1 & $\perp$ & - & $\perp$ & - \\
\hline & Epicidyn & & 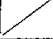 & $\perp$ & +1 & 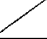 & $1-$ & & r \\
\hline
\end{tabular}

Notice: Mark follows to the Table 2

d) 病理組織学的所見: 初代生菌接種 猫 No. 6 の滕 べき淋巴腺の淋巴洞内红組織球性細胞の小集篇がありそ の中心少数の抗酸菌が貪喰されている像がみられた。但 しその他の㖪器には特にい5经どの組織学的病像はなか Dた。

累代生菌接種猫 No. 9 に於ては，肝の盘管壁周国並 びに肺胞壁に於て中央部はやや变性した類上皮細胞より なりその周国は組織球性細胞，リンパ球及び少数の多形 核白站球の浸潤よりなる小病栄が認められ，而子その病 单中比は Ziehl一ーマキシリン染色で怯被染性やや不良 な短形抗酸菌が少数点在していた。な括この No. 9 の その他の臟器並びと死菌累代接種 No. 11 とは認むべき 所見はなかつた。

以上を総合すれば生菌接種猫に於ては時として，その 淋肥腺，肺，肝文は脾に鼠瀨細胞が底跡的ながら出現す 
るととの心るととが筧知できるが但しとのよらな場合て もそれら小病单部内よりの検出抗酸菌はその被染性にし ても，形態にしてももしろ退行的傾向を示すように見受 けられるととも判つた。

e）白鼠への復元接種㪽見: 初代生菌接種猫 No. 6

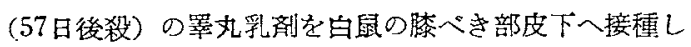
たととろ 308 日後の所見ではその接種局所に $2.5 \mathrm{~g}(2.7$ $\times 1.7 \mathrm{~cm})$ の鼠癩性大肉芽腫が認めら九，又体内红抗酸 菌が Table 4k示したよらに広く而もかなりの濃度に 播有しているととがみられた。即ちとのことにより鼠瀨 菌は少くとも2 月晭ほどは異種動物でるる猫の体内て な颃感染力を充分保持しらるものでるるととがわかつ た。

Table 4. Degree of the distribution of acid-fast bacilli in the bodies of rats reversely inoculated with the leprosy bacilli after cat passage

\begin{tabular}{|c|c|c|c|c|c|c|c|c|c|c|c|c|c|c|c|c|c|c|c|c|}
\hline \multirow{3}{*}{ Inoculuen } & \multirow{3}{*}{\begin{tabular}{|l} 
Survival days of \\
inoculated rats
\end{tabular}} & \multirow{3}{*}{ 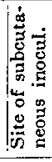 } & \multicolumn{12}{|c|}{ Lymph nodes } & \multicolumn{6}{|c|}{ Vicersl organs } \\
\hline & & & \multicolumn{2}{|c|}{$\begin{array}{l}\text { Knee } \\
\text { fold }\end{array}$} & \multicolumn{2}{|c|}{ Inguinal } & \multicolumn{2}{|c|}{ Axillary } & \multicolumn{2}{|c|}{ Cervical } & \multicolumn{2}{|c|}{ Iliac } & \multirow{2}{*}{ 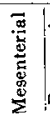 } & \multirow{2}{*}{ 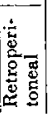 } & \multirow{2}{*}{ 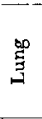 } & \multirow{2}{*}{ 总 } & \multirow{2}{*}{\multicolumn{2}{|c|}{ 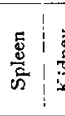 }} & \multirow{2}{*}{ 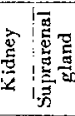 } & \multirow{2}{*}{, } \\
\hline & & & $\mathrm{r}$ & 1 & $\mathbf{x}$ & 1 & $r$ & 1 & $\mathrm{r}$ & 1 & $\mathbf{r}$ & 1 & & & & & & & & \\
\hline $\begin{array}{l}\text { Testicle suspension } \\
\text { from cat (No. } 6 \text { ) } \\
\text { killed af ter } 57 \\
\text { days in the group } \\
\text { of lst generation }\end{array}$ & 308 & $\infty$ & $\infty$ & \pm & H & + & \# & 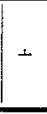 & + & + & $H$ & $\perp$ & \pm & \# & $\perp$ & $\perp$ & $\perp$ & $\perp$ & $\perp$ & \pm \\
\hline
\end{tabular}

\section{第 2 章 ヌートリアに対する接種実験}

\section{1. 実験方法}

a) 供試獣：体重 $1,100 \sim 1,200 \mathrm{~g}$ のヌートリア 3 匹と 対照として体重 100〜200g の白鼠4 匹とを使用した。

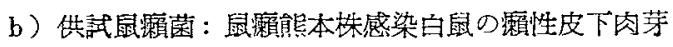
腫（接種後270日）よりの生塩水に上る15倍乳斉を1,000 r. p. m., 5 分蘭道沈してえられた上清を体重 $150 \mathrm{~g}$ につ き $0.5 \mathrm{ce}$ 宛腹腔内心接種し，同時に右側膝へき部皮下に む $0.5 \mathrm{cc}$ 宛淁種した。

c）観祭：週 1 回の体重の測定及び体表変化の観察の 他に获接種後 1 日，4日，7日，10日，2週，3週，4 遠，5週，6週，7遠，8週，9週，10週，11週及び12 㥜目に前出の第 I章の実験 Iに準して採取して作つた腹 䶼液よりの泬抹染色標本心ついて腹腔内出現細胞，呤菌 細胞及び細胞外遊離玾酸菌の時間的推移を追究した。

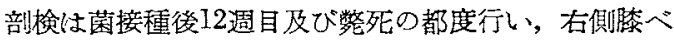
き部の接琶局所, 淋巴腺及び内葴について肉腿的变化を 観察した後それらよりの叙抹染色標本並びに組織划片標 本をつくりそれにより抗酸菌の体内播布の程度を追究比 較するとともにそれらの病理組織学的所晃についてす检 討孝加えた。

\section{2. 実験成績}

a）一般状態並びに体表変化：ヌートリア No. 3 は 菌接種後著しく体重が淢少し，るい瘦して29日目に擎死 したが，その他の試獣にはすべて著変なく体重す漸增し た。触診的には右側陵へきき部の菌接種局所に, 白鼠では 菌接種後 4 週頃から浸潤を，又ヌートリアでは同 9 週後
頃より可成り硬い移動性破結をそれぞれ触れるよらにな つた。

b）腹腔液の所見：菌液を皮下及び腹腔内に同時に接 種した後の的期には腹涳液に可成りの湿濁がヌートリア に於て認められたが，それる1週前後て透明となつた。 白国には終始腹腔夜の混濁するととはなかつた。

腹腔内出現細胞としては中性好性白血球，単核球のは が淋巴球，エオヂン好性白血球，箓膜細胞及び肥涌細盷 が㛟出され，との点前述の鼠瀨菌の猫腹腔内接種実験の 場合と大差はなかつた。

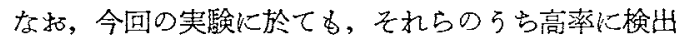
されたすの中性好性白血球及び単核白典球で岁つた が，とれらの推移についてはまとめて Fig. 5, Fig.6に 示した。

即ちとれでかかるよらに感受性動物である白鼠に於て は前述の第 1 章の実験 I のさいの白鼠化於ける所見と全 く一致して接種後 1 日目には中性好性白血球と単核球の 出現頻度には大差なく，従つて接種 4月前後におけける れら雨種細胞の推移曲線には交攴がおとるととなしに前 者は経日とともに漸減の，及後者は反対に漸増の一途を 趉る傾向を見せた。之に反してヌートリアに於ては中性 好性白血球か経日に往つて漸減し，単核球が汉刘に漸增 する点に於ては上訅の白鼠の場合と傾向を等しくしては いたが，他力両種細胞の推䔟曲線がNo. 1 以外のもので は接種 4.日前後から14日後項までにそれぞれ共に2 国は とも明らが交义した点に於て占鼠に於计る所見と著し い相違を示した。

次に脍菌細胞の時間的推移はまとめて Fig. 7 及び Fig. 
8 に示した。

Fig. 5. Transition of neutrophil leukocytes and monocytes appeared in the peritoneal cavities of nutrias

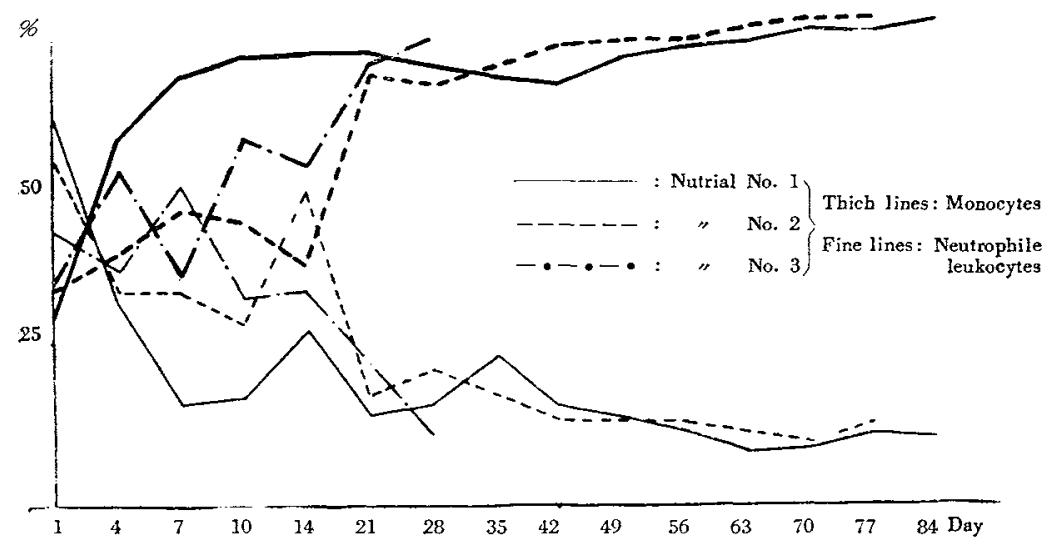

Days after inoculation

Fig. 6. Transition of neutrophile leukocytes and monocytes appeared in the peritoneal cavities of rats

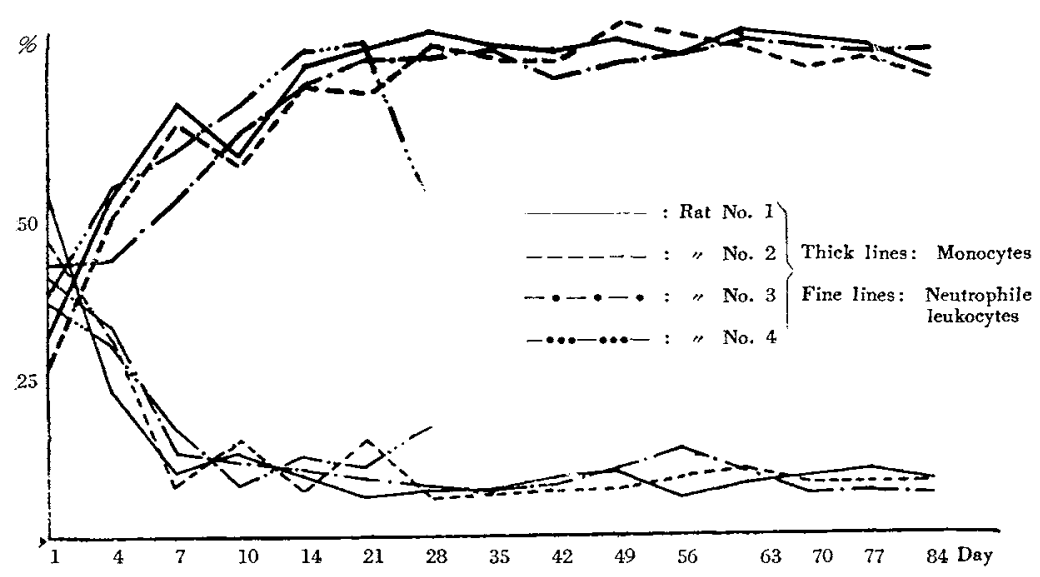

Days after inoculation 
Fig. 7. Transition of phagocytes in the peritoneal cavities of nutrias

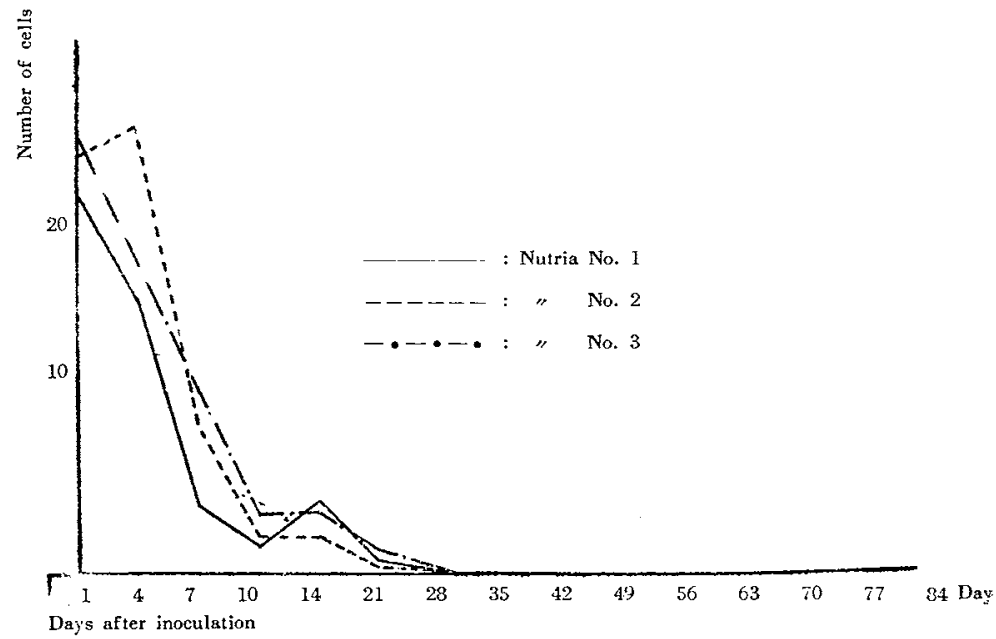

Fig. 8. Transition of phagocytes in the peritoneal cavities of rats

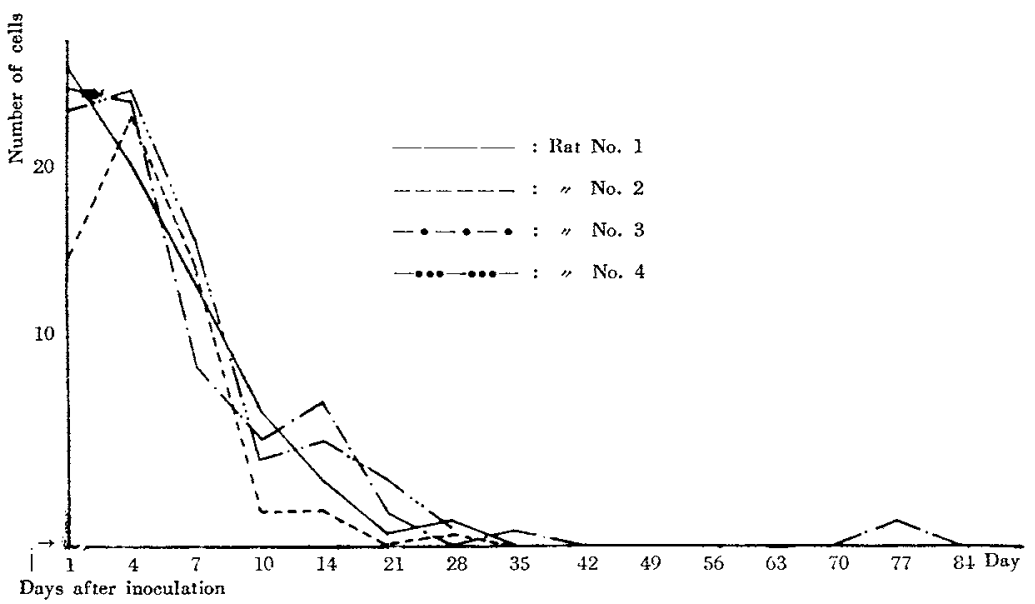

即ち腹腔内哙菌細胞は白鼠に於てもヌートリアに放つ

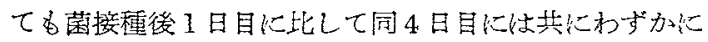

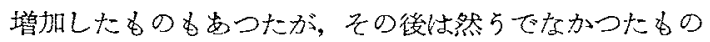
と共比とともに比較的急速に娍少の佔向を巡るとと画 者全く癸一にてていた。ただ強いていいばその完全消

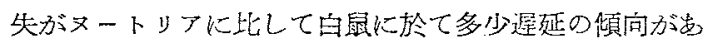
るよらですつた。な如, 白鼠 No.3のみで接種11通後 に再び少数ながら Globi 状仍至散在性の抗酸菌を貪飡し た獎膜細胞の再出現が認められた。

な怙，貪喰細胞の種類は猫及び白国に於けると同椂， ヌートyアに於ても単核球が殆どを占めその优に稀に中 性好性白而球及び獎膜細胞がるられた。

次に㙏腔内細胞外の遊離抗酸菌についてみるに Table
5 に示したよらに、ヌートリアでは21日以後にはこの種 の菌影加全く認められなかつたの心反して自四に於ては 21 日後頃にも認められそれからしばらく認められなくな つたが再び接種後 9 週及ひ11逜目には認められるように なつた。

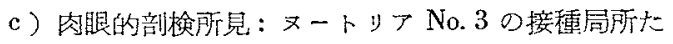

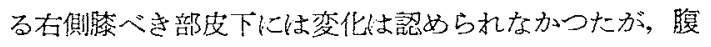

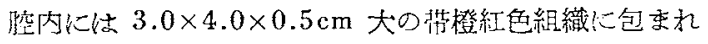
た腄瘁が，腹膜及び小腸と癒着して存在して扣り゙，これ の切断面は蜂埛状を示し内に黄色膿熄を容れていた。同 No. 2 では右側㮏へき部皮下に $1.3 \mathrm{~g}(2.0 \times 1.5 \mathrm{~cm})$ の 硬弾力性腫瘤が周国組織と限局して存在し，又大䋨及び 腸間膜には醀稙大結節が多数訨明された。さらに同 No、 
Table 5. Transition of the extracellular acid-fast bacilli in the peritoneal cavities of nutrias and rats

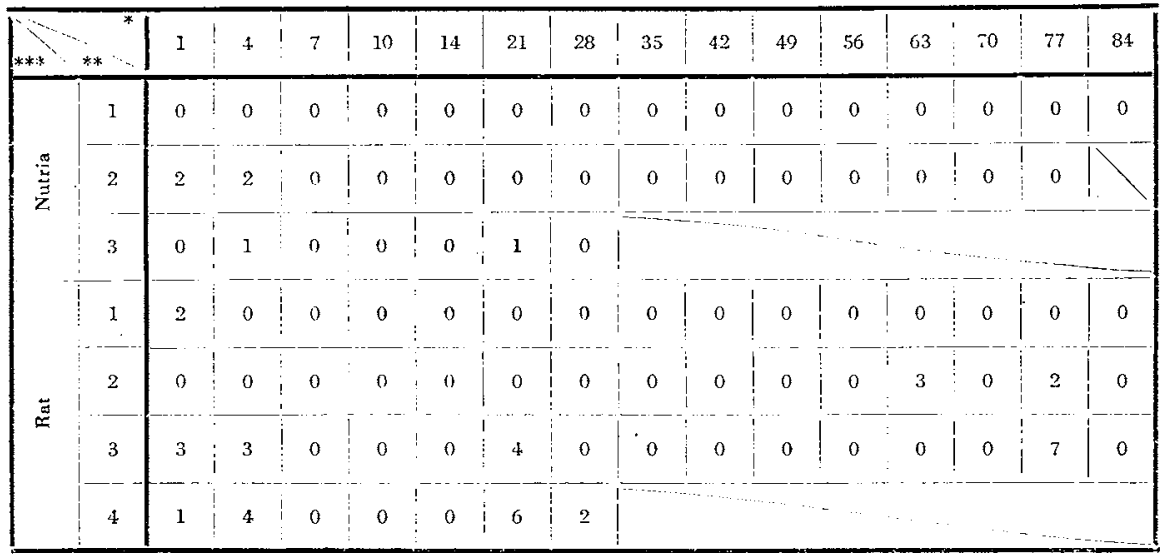

Notice: The number shows the bacilli detected from 100 microscopic felds

* Day ** No. *** Animals

1 の右側膝べさ部皮下にも上記 No. 2k怙けると同性状 D $2.1 \mathrm{~g}(2.3 \times 1.5 \mathrm{~cm})$ の腫㢞が愁められたがこの例で

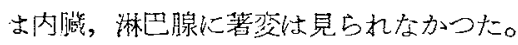

白鼠に於てはいずれも在側膝べき部灾下に膜状のうす

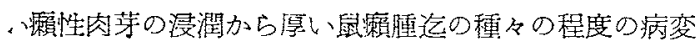
が弪められたが，それらの肉眼的性状は上記のヌートリ

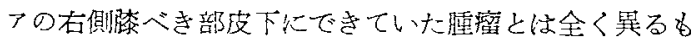

のでかつた。その他NNo.4の右側膝べき部剌巴腺には乾

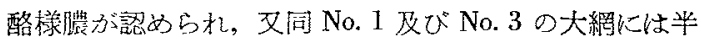
米粒大から賴䊀大の黄色結節が多数見受けられた。

d) 㭷菌学的所罗：抗酸菌の体内播布度は一括して Table 6 に示したが，乙れでみられるよ5にヌートリア に於ては白鼠に比して接程局所皮下の抗酸菌分布が著し く少い代かりでなくその他にその生存日数が長くなるに

Table 6. Degree of the distribution of acid-fast bacilli in the bodies of nutrias and rats

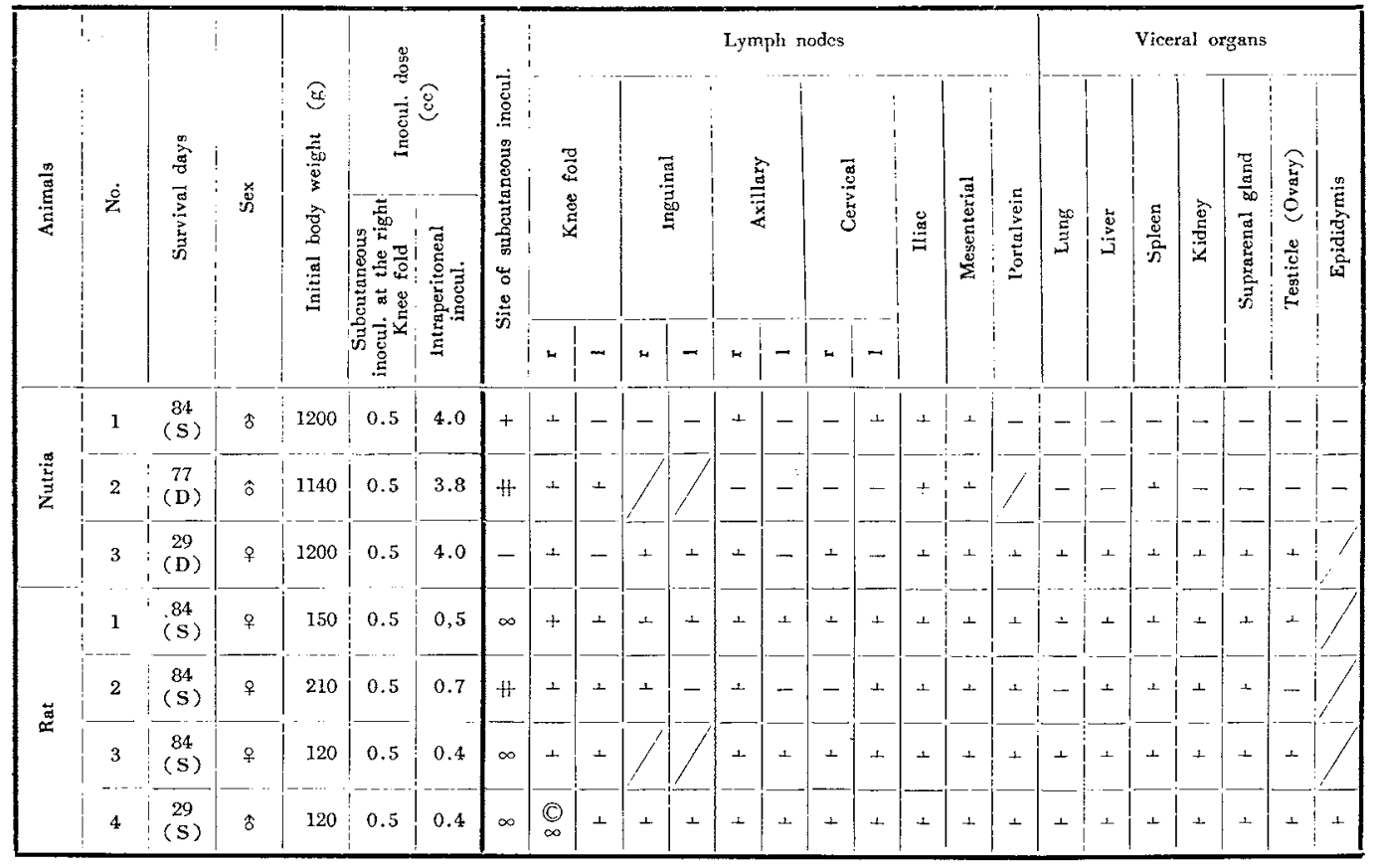

Notice: (C) Caseation 
つれて抗酸菌の体内播布度が低下して行くような所見も 認められた。その他一般に云つて体内分布の抗酸菌の形 態す白鼠体内のすのに比してヌートッア体内の菌に於て はとくに顆粒形のすのが多いよらであつたが，併し菌の 被染性に於てはヌートッフ体内のものでも白鼠体内のる のと结济同様，な怙充分良好であつた。

な抢，前記のヌートリアNo. 3 の腹腔内腫瘦中の膿に はき和好多数の顆粒の判然とした抗酸菌がそれぞれ椧 出されたととを附記して扔きたい。

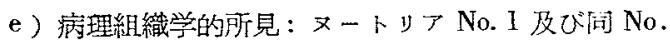
2 に於て热められた右側㯟べき部皮下の腫溜は，中心部 には乾酪化がみられその周四は組織球及びプラスマ細胞 よりなる肉芽にかと亦れていたが，その中に定型的鼠桷 細胞は証明されなかつた。なお，乙れら浸潤細胞内外に は被染性やや不良で顆粒の判然とした抗酸性短桿菌が散 見された。な抢，その他の淋巴腺，内藏のいずれにもい わかる鼠瀬細胞は証明されなかつた。

\section{総括並ひに考按}

既に市原 ${ }^{16}$ は鼠瀨菌の猫への接種実験て，接種局所の 軟化乾酪様膿から 4 力月迄菌检出を認め, 又淋巴腺か 5も3 カ月迄それを認めているがそれ以上㭘出不能で あり, 白鼠への復元接種む 3 カ月迄陽性ですつたと報告 している。今回の著者の猫を用いての実験に於ては接種 後早期们可成りの猫の整死が为つた為必ずしも成績の正

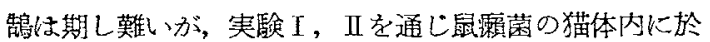
ける播布度は白鼠に於けるそれに比して可成り劣り，且 又生・死菌接種耐群間に於てさ克も著昭な差異は認めら 机卞解女猫体内の鼠霜菌には短形乃至顆粘形が多く認め られた。だで実験Iの生菌接種猫 No. 1 の睪丸には多 数の恰を Globi 前期像の如き增殂の所見が認められ，志 るいは猫の睪丸内ではむる程度鼠瀨菌の增殖が起り得る ととも岁るのではないかと思わ就たが，反復して猫を供 試して行つた実験Iに於ては遂にそのような睪丸内所見 はえられなかつた。

その他の前述のような鼠霜菌接種猫についての細菌学 的及び病理組織学的所見と如上の成綪とよりして究極の ところ猫炕は鼠瀨菌炕対して感受性がないるのと考えて 大過ないであろら。な拓，著者の場合に於ても市原 ${ }^{16}$ の 成精のように白鼠への復元接種によつて少くとも2 月月 位猫体内で鼠制菌怯その白鼠への感染力を保持してい るととがわかつた。

次にヌートリアについてであるが,ヌートリア (Myoca-

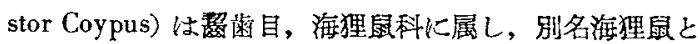

云われる水陸両棲動物ですつて, 之は動物分類学上, 食 肉目，猫科の猫よりはむしろ鼠科近いととろより今回 あえて之をとりあげて，その鼠瀨菌に対する感受性の有 無乃主程度について検討したわけでめるが，その実験成

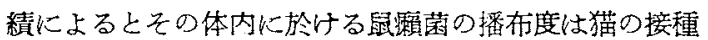
実験の場合と活隹似ていて対照の白鼠体们に於けるそれ よりる可成り劣ることがかかつたのみならず菌接種局所 皮下儿は䃭い腫癌が凡て形成されはしたがその部に於て 鼠制菌の增殖像はむしろ陰性と云うべきで岛り，文病理 組織学的にも定型的鼠癩細胞は該部のみ在らず内䑏及び 淋巴腺のいずれに於ても証明できなかつた。とれらのと とからすれば，該腫瘤は白鼠皮下に見られるよらな瀨性 肉芽とは異り一時的の反忘性病变と解粮した方が妥当で はないかと思われる。

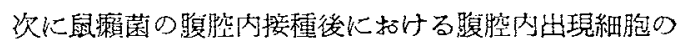

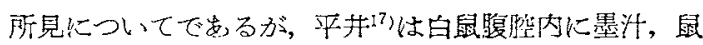
顆生菌，同死菌を注射した結果，最衫は中性好性白血球 の遊走が盛んでまり，I週前後に単核球の增加を認めた 々報告しているが，今回の著者の猫，ヌートリア及び白

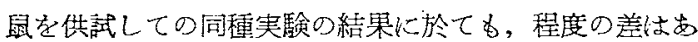
るが㤬ぼ同様の傾向が認められた。又これは腹腔内接種

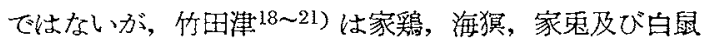
の皮下に人瀨菌，鼠䚄菌及び仮性鼠瀨菌を接種すると接

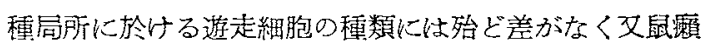
菌及ざ人濑菌を白鼠に接種したさいには前者は增檤する

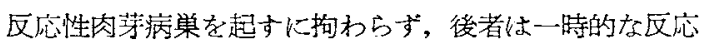
性肉芽病变を起すに過ざなととを報告して喆り，之を 今回の著者の成績と併せ考元る時, 鼠櫴菌接種によつて 出現する細胞の種類はその菌に対する生体の感受性，非 感受性とはむしろ関倸が少いのではないかと思われる。

ととろが眮味出るととに红今回の著者の実験結果より すれば，鼠軞菌腹腔内接種後の腹腔内出現細胞の時間的 推移に於ては之を仔細に見て行くと多少とる生体の鼠濑 菌感受性と関連性があるのではないかと思わせられるよ らな所見に接し得たのである。即ち，先ず最㲊菌炕対し て感受性動物であるところの白鼠代於ては鼠㴶菌の腹腔 内接種後 1 日目には生・死菌接種の別なく中性好性白血 球と単核球の出現频度には著盖は見られなくて，而もそ のまま 4 日目頃からは前者は减少の，又後者は增加の一 途を迱つて行つたのでてかか両種細胞の推移曲線には 交叉は全く起らず終つた。(Fig. 2)。

之に対して猫に於ては (Fig. 1) 接種瑟日には既に単 核球に比してはるが多くの中性好性白血球が出現した のに，その後4日目頃になると前者は漸増し，逆後者 
は漸減したために，とれら両種細胞の推移曲線には明ら かな交叉が抢とつた。又ヌートリフに於てる（Fig. 5) 両種細胞の推移曲線がNo. 1 老除いて接種 4 日目前後か ら14日後頃迄にそれぞれ共に 2 回ほども明らかに交叉し た点に於て上記のよらな白鼠に於ける所見 (Fig. 2, Fig. 6）上は明確に異つていた。但し，その後の経日につれ ての単核球の漸增と中性好性白血球の漸減々の傾向は猫 及びヌートッアに於ても白鼠とはぼ登を一炕していた。

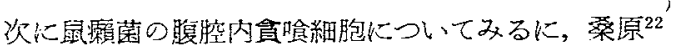

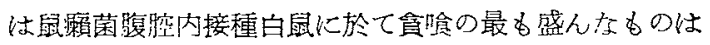
単核細胞で虫り，次で中性好性白血球，内皮細胞であ り，細胞外化遊離した菌白早期に消失するととを述べて 怙り, Chaussiand, R. et Toumanoff, C.23) 恃生・死瀨菌

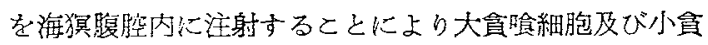
嗆細胞が出現し，遊離菌はきわめて速に腹梳液から消隇 したと報告している。これらの報告は今回の著者の実歌 に於て，鼠瀩菌の接種せられた腹腔内に於ける貪哙細胞 としては接種後早期には中性好性白血球がむしろ多いが 感受性動物たる白鼠で汒その後閒もなく単核球が急速に 増加し逆に中性好性白血球が急速に減少し，猫やヌート リアではその傾向がそれ程急速著明ではなく従つて両種

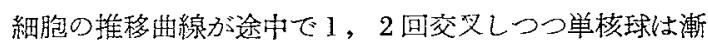
增し逆に中性好性白血球は潮減し結局に於て㝊はり単核

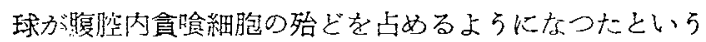
所見とほぼその撜を一比するすのといつてよかるら。な 拓，又著者の場合にも細胞外遊離挖酸菌が比較的早期に 消減したがこれ亦如上の報告と一致する所見でもつた。

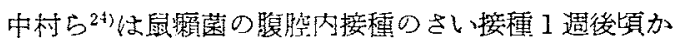
らは非抗酸性万至弱抗酸性の桿菌が認好らるようにな り 2 调目には抗酸性桿菌が凡て細胞内に存在するように なり而为それら比分裂，発芽等の增犆像が朋睹となり，

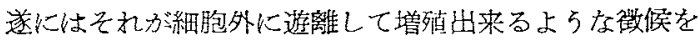
示すといつているが，平进17 や市来 ${ }^{25}$ 的遊走性細胞内で の鼠灀菌の堌殖は土否定している。著者の実験に於ても前

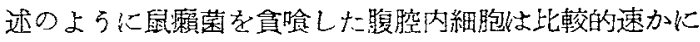
減少し，それらの遊走細胞内での鼠瀨菌の增殖像とい口 たものは認め難かつた。但し，前出第 2 章のヌートリア に対する接種実験に於ける対照として供試した白鼠NNo.3

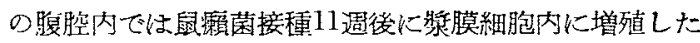
と思われる像を示す抗酸菌を検出するととがてきたが， 之は平井 $\left.{ }^{17}\right)$ が領喰能をもつ細胞でも組織固定性のもので 仕鼠覤菌の增殖が欢られるが，復腔内細胞の上うな遊走 性のもので注それは増殖しないといらているととからす れ仗，或は予め鼠霜菌の增殖した固定性漿膜細胞が腹腔
内に剥離したものを観察したのではないかとも考えられ る。

\section{結論}

1 ，猫の䠦腔内に接種された鼠瀨菌は，その睪丸内て は多少とる增殖したかの像宗す場合すめつたが，一般 には 2 カ月後になつても感染の像を示すことがなかつ

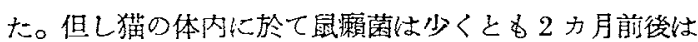
その白鼠への感染力を保持しらる。

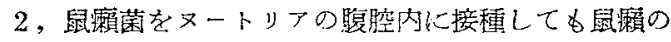
感染は成立しない。

3 , 腹腔内遊走細胞内での鼠瀨菌の堌殖像は，猫及び ヌートッアに於てのみならず白鼠に於てる認め難い。

4 ，鼠嶰菌接種後の腹腔内出現細胞俚，その種類に於 ては白鼠と猫及びヌートリアとの間以著差はないが，そ の5ちの単核球と中性好性白血球との経日的增减推移相 には白鼠と猫及びヌートリフとの間にはかなり顕著な差 がもる。

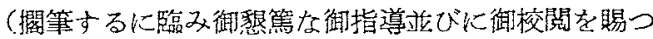
た恩師占部教授及び病理組織学的倹索に於て御教示を项 いた病理学教室山田助教授に梁く感謝する。

\section{参考文献}

1) Muir, E. and Henderson, J. M.: Rat leprosy, Ind. Jour. Med. Res., 15,807 (1927)

2) Lowe, J.: Studies in rat leprosy, Ind. Jour. Med. Res., 22,187 (1934)

3) Marchoux E. et Chorine V.: La sensibilitè au virus lèpreus n'est pas plus grande chez les jeunes que chez les adultes, Ann. Inst. Pasteur, 57,583 (1936) (Zbl. Bakt., IAbt., Ref., 125,447 (1937) 上り引用）

4) Sellards A. W. and Pinkerton H.: The behavior of murine and human leprosy in foreign host, Am.

J. Path., 14,421 (1938)

5) Pinkerton H. and Sellards A. W.: Histological and cytological studies of murine leprosy, Am. J. Path.,14,435 (1938)

6) Marchoux E. et Chorine V.: Cinq bacilles de Stefansky suffisent pour infecter le rat blanc, Ann. Inst. Pasteur, T. 61,296 (1938)

7) 戸田忠雄：人癞菌，鼠嚓菌及び自然界抗酸性菌 の研究，レプラ，12，1（昭16）

8）浸辺義政：霜の実験的研究，レプラ，12, 607 (昭16) 


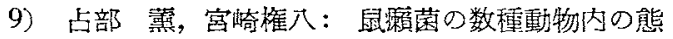
度，日本医学及健康保傅，3247，1500（昭18）

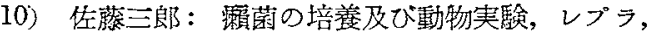
18,19 (昭24)

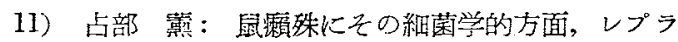
18,39 (昭24)

12) 谷村忠保：鼠㿎（昭28）服大皮膚科教空登行

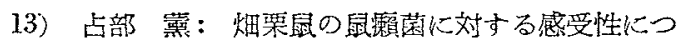
いて，東京医誌，3055，2762（路22）

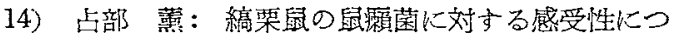
いて，東宗医誌，3098，2289 (昭23)

15）高山保郎：瘦菌の異種動物接種に関する研究， 第 1 報，レプラ，22,131（昭28）

16）南原鶴雄：猫及び $2-3$ 鳥類を以つてせる鼠嬾 菌接蒩試駼，レプラ，18，59（昭24）

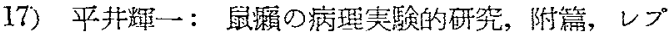
$\bar{j}, 21,240$ (炤 27)

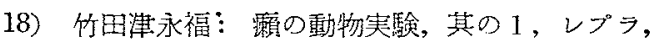
16,39 (昭22)

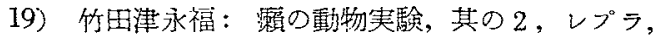
16, 41 (路 22)

20) 竹田津永福：漕の動物実験, 其の 3，レプラ, 16, 53 (昭22)

21）竹田津永福：虂の動物実験，其の 4，レプラ， 17,61 (昭23)

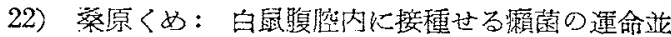
びに其の組織学的所見について，レプラ，16，21 (昭22)

23) Chaussiand, R. et Toumanoff, C. : Les réactions cellulaires et la phagocy tose chez les cobayes inoculés par voie intraperitonéale avec des bacilles de Hansen viant ou morts, Ann. Inst. Pasteur, 85, 713 (1955) (Zbl. Bakt., IAbt., Ref., 156,316(1955)より哥用)

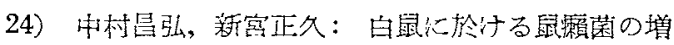
殖態度（其の1），レプラ，21，118（昭26）

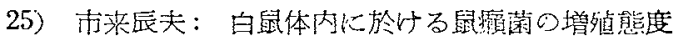
関与る研究，医学研究，25，225（昭30） 